How to cite this paper:

Stejskal, J., Hajek, P., \& Prokop, V. (2018). Collaboration and innovation models in information and communication creative industries - the case of Germany. Journal of Information and Communication Technology, 17 (2), 191-208.

\title{
COLLABORATION AND INNOVATION MODELS IN INFORMATION AND COMMUNICATION CREATIVE INDUSTRIES - THE CASE OF GERMANY
}

\author{
${ }^{1}$ Jan Stejskal, ${ }^{2}$ Petr Hajek \& ${ }^{1}$ Viktor Prokop \\ ${ }^{1}$ Institute of Economics Sciences \\ Faculty of Economics and Administration, \\ University Pardubice, Czech Republic \\ ${ }^{2}$ Institute of System Engineering and Informatics \\ Faculty of Economics and Administration, \\ University Pardubice, Czech Republic
}

jan.stejskal@upce.cz;petr.hajek@upce.cz; viktor.prokop@upce.cz

\begin{abstract}
In rapidly changing environment of global knowledge economy, innovations play an important role in the process of gaining competitive advantage. Specifically, information and communication creative industries are dependent on constant technological breakthroughs, new sources of knowledge and high innovativeness. Moreover, new knowledge and innovation outputs of these industries subsequently affect products and processes of other businesses as well as innovation activities within different industries. Knowledge acquisition, utilization and dissemination therefore represent important processes that significantly influence the firms' innovation activities. It was proven that cooperation is an important determinant that helps to spread the existing knowledge and to create new knowledge through knowledge spillover effects. The paper deals with the determinants of cooperation and innovation to examine numerous effects on both activities in German information and communication creative industries. We also test the role of the determinants of innovation performance and their influence on the economic effect of innovation activities in terms of
\end{abstract}


the percentage of innovative products in total turnover. For our analyses, we are using data from Community Innovation Survey 2008-2010. We empirically show that firms from German information and communication creative industries can create innovations through the collaboration and confirm that both internal and external communication significantly contribute to the creation of innovation. Moreover, we confirm the influence of internal expenditures on $\mathrm{R} \& \mathrm{D}$ and observe significant influence of external expenditures on R\&D. In conclusion, we also provide some practical implications for policy makers.

Keywords: Creative industry, knowledge acquisition, collaboration and innovation models.

\section{INTRODUCTION}

Nowadays, in the era of knowledge and knowledge-based economy, traditional production factors such as labor and capital are subsequently substituted with other significant factor - knowledge. Knowledge economy is focused mainly on human potential (and also capital) and emerge within the context of the economic analysis of the quality of the input factors in the production processes. On the other hand, knowledge-based economy has added the structural aspects of technological trajectories and regimes from a systems perspective that leads to discussions about intellectual property rights as another form of capital and focuses directly on the production, distribution, and use of knowledge and information (Cooke \& Leydesdorff, 2006). The concept of a knowledge-based economy is simply a concept that serves to direct the attention of policy-makers to science and technology issues as well as knowledge-intensive activities (Godin, 2006; Marrano, Haskel \& Wallis, 2009). Thus, knowledge and its creation, dissemination and using (specifically for generating innovations) provides critical sources of competitive advantage (Stejskal, Merickova \& Prokop, 2016; Prokop \& Stejskal, 2017).

There is a growing recognition by researchers and practitioners about the importance of knowledge as a crucial source for competitive advantage (e.g. Carneiro, 2000; Holsapple \& Singh, 2001). Krugman (1994) divided the concept of competitiveness in three different perspectives, namely microeconomic, mezzoeconomic and macroeconomic level. In terms of the microeconomic level, competitiveness refers to the ability of the entity (e.g. firm) to compete, be profitable, develop and grow (Porter, 2004). The competitiveness of firms is derived from the competitive advantages that 
firms create through their strategy and actions in the markets and through their ability to deal with knowledge in efficient way (Prokop \& Stejskal, 2015). In contrast, the competitiveness of regions at the mezzoeconomic level cannot be expressed simply as the sum of the efforts and achievements of the firms in the region (Balkyte \& Tvaronavičiene, 2010). Regional competitiveness is a result of the activities of various institutions and organizations working in the same environment, including knowledge-intensive organizations such as universities and research organizations (Kitson, Martin \& Tyler, 2004). Defining the macroeconomic competitiveness of countries is very different from corporate competition and is a controversial issue (e.g. Charrass, 2016) therefore researchers attempt to find a similar type of relationship between the power of countries and their macroeconomic level of competitiveness because in a new global economy, nations (like corporations) are engaged in win-lose competition for global markets (Ulengin, Ulengin \& Onsel, 2002).

Innovative processes are considered as the key factors of both firm competitiveness and the performance of the whole national economy. Therefore, these processes should be supported by public policies (Merickova \& Stejskal 2014), because innovations are closely associated with research, development and new technologies. Due to cost-cuts and time-cuts for acquiring new knowledge, firms and other institutions are using collaboration as production factor (Laperche, Lefebvre \& Langlet, 2011; Ali et al., 2016). It is mainly a collaboration of universities and private firms that leads to innovation networks and to the transfer of knowledge (Siegel et al., 2003). Innovations are currently not generated in one firm in isolation, but mostly in the cooperative based networks that allows creation of knowledge spillover effects. Moreover, innovations are relevant to a particular region which provides essential production factors. Thus, there exists a natural connection between these concepts and many studies have analysed firm competitiveness in specific regional and industrial settings.

Recent studies for manufacturing industries have shown that collaboration with other entities allows the effective use of the acquired knowledge, resulting into increased innovation activity (Belderbos et al., 2004). However, little attention has been given to creative industries that have increasing potential to create wealth. This paper aims to fill this gap and to analyze determinants of cooperation and innovation to examine numerous effects on both activities in German information and communication creative industries. We also test the role of the determinants of innovation performance and their influence on the economic effect of innovation activities in terms of the percentage of innovative products in total turnover. This is an extended version of Stejskal \& Hajek (2016), where we analyzed the innovation determinants of creative 
industries in the Czech Republic. Here we focus specifically on information and communication creative industries in the context of the most competitive European economy. We also perform more in-depth regression analyses in the current study.

The remainder of this paper is structured as follows. In the next section, we present a theoretical background for the innovation determinants in information and communication creative industries in Germany. Section 3 provides the characteristics of the dataset and the research methodology. Section 4 provides the experimental results. In Section 5, we discuss the obtained results and conclude the paper with suggestions for future research.

\section{THEORETICAL BACKGROUND}

In the context of firm innovation activity, regional level is emphasized for several reasons: (a) the regions are increasingly becoming the drivers of development; (b) there is a considerable allocation of production factors, which are moved to places with better (cost) conditions for production; (c) there are no macroeconomic stabilizers at the regional level (such as devaluation of the exchange rates and the flexibility of wages and prices, migration of mobile factors), i.e. capital and labour can become a threat for the region; (d) regional competitiveness is also influenced by the decentralization of public innovation policies, often there is a shift of decisionmaking and coordination of activities towards the regional level (Porter, 2003; Skokan, 2004; Chapain \& De Propris, 2009; Blažek et al., 2011).

Innovative regions have a high level of productivity and labour forces. Regions with a higher productivity usually achieve a higher economic growth. They create and attract investments (especially FDI) and associated jobs. Productivity is defined through the value of goods and services produced per unit of labour and capital and the development in recent years has demonstrated that competitiveness is based on productivity level (Porter, 2004). To maintain competitiveness, firms have fundamentally changed the attitude to production factors in the last decade. Whereas the old approach was based on optimal cost and efficiency, the new one is based on knowledge, innovation and creativity. Productivity is affected not only by public policies, laws and macro-economic framework but also by innovation milieu and the firm performance and sophistication of firm strategies (Karaev et al., 2007).

With the development of the knowledge economy, the characteristics of competitive advantage have dynamically changed (i.e., the ways of competition, the sources of competitiveness, etc.). Porter et al. (1998) analysed the various stages of competitive development. In the long term, the successful economic development is the process of gradual recovery, when the national innovation environment evolves 
and promotes the growth and productive ways of competing firms that operate in the same region (Lucas, 1988). The development of the country can be divided into four stages. The first three stages are called economy driven by (a) production factors, (b) efficiency and (c) innovations. These three stages reflect improving national prosperity. The fourth stage is called economy driven by prosperity. When the region gets to this stage, there is a lock-in problem, the dynamics of innovation is reduced and competitiveness can be decreased (Skokan, 2004).

In each of these stages, the economy is stimulated by various determinants; there is another innovative environment (milieu) where the innovation processes are taking place. The innovation process of enterprises differs substantially between various industries whose innovation activities require specific knowledge bases (Asheim \& Gertler, 2005; Hajkova \& Hajek, 2014). Asheim et al. (2007) highlight the need for specific knowledge in creative industries. They introduced symbolic knowledge, which is characterized by a distinctive tacit component and high context-specificity. Although creative industries also draw on an analytical knowledge base, which relies on codified knowledge and university-industry links, symbolic knowledge is essential in the creative process. The knowledge required by creative industries is often narrowly tied to a deep understanding of the habits and culture of specific social groups (Asheim \& Hansen, 2009). Therefore, this type of knowledge tends to be generated in interpersonal (face-to-face) interactions, this is via socialization. In this process, "know-who" knowledge (of potential collaborators) is acquired.

Contrary to synthetic knowledge, which is typical for engineering industries, symbolic knowledge is less sensitive to regional economic and institutional structures. Another distinction lies in the knowledge creation process. Synthetic knowledge is usually created via interactive learning with customers and suppliers, whereas symbolic knowledge is gained through learning by working in project teams (Asheim \& Hansen, 2009). CameloOrdaz et al. (2012) included additional determinants of innovation activity for enterprises in creative industries and demonstrated that the entrepreneurial characteristics (previous experience and value system) positively affect the innovation performance of small enterprises in creative industries. Moreover, information and communication creative industries are characterized by high innovativeness and dependence on constant technological breakthroughs and products and services resulting from activities of these industries cause significant changes in business processes of other industries by increasing efficiency and productivity (Turuk \& Labas, 2015). Therefore, timely diffusion of new technologies and its adoption are important factors promoting macroeconomic growth and understanding the factors determining technology 
adoption as well as firms' innovation and collaboration activities are thus highly relevant topics, not only from the policy point of view (Hollenstein, 2004; Ramayah et al., 2013).

\section{DATA AND RESEARCH METHODOLOGY}

For the data collection we used a harmonized questionnaire of EU Member States from the Community Innovation Survey (CIS). The survey was carried out in the Czech Republic for the period 2010-2012 by combining sample (stratified random sampling) and exhaustive surveys taking into account the regional dimension of NUTS3. In total, data on 6,328 German enterprises with at least 10 employees was obtained. Enterprises in selected sectors of information and communication creative industries were then incorporated in our sample: (1) Telecommunications (wired, wireless, satellite and other telecommunications activities) (NACE code: J61), (2) Computer programming, consultancy and related activities (NACE code: J62), and (3) Information service activities (data processing, hosting and related activities, web portals and other information service activities) (NACE code: J63). These industries covered 311 out of the 6,328 enterprises in the dataset. The list of sectors is based on recent literature (Bakhsi et al., 2013; Boix et al., 2013) and follows the methodology for the classification of emerging industries (Monfardini et al., 2012). The basic characteristics of the dataset are given in Table 1. The innovation activity of information and communication creative industries was estimated by two output variables: (1) by calculating the number of enterprises that introduced a new product or service to the market, and (2) by the percentage of innovative products in total turnover. We are aware that these variables may fail to capture all forms of innovation in this sector due to less formalized innovation processes, strong structural dynamics and difficulties in measuring outputs of creative industries (Miles \& Green 2008; Kimpeler \& Georgieff, 2009). On the other hand, this approach enables comparative analyses in innovation performance across sectors (Müller et al., 2008).

Table 1

Average Values of Numerical Determiants for German Information and Communication Creative Industries

\begin{tabular}{lcc}
\hline & \multicolumn{2}{c}{ Innovative } \\
\hline \multicolumn{1}{c}{ Determinant } & NO & YES \\
\hline $\begin{array}{l}\text { Total turnover (TURN) in mil. EUR } \\
\text { Percentage of innovative products in total turnover } \\
(\text { TURNINNOV) }\end{array}$ & 27.0 & 318.8 \\
\hline
\end{tabular}

(continued) 


\begin{tabular}{|c|c|c|}
\hline \multirow[b]{2}{*}{ Determinant } & \multicolumn{2}{|c|}{ Innovative } \\
\hline & NO & YES \\
\hline Employees with a university degree (EMPUD)* & 4.19 & 4.57 \\
\hline R\&D expenditure internal (RDINT) (\% of total turnover) & 1.71 & 6.02 \\
\hline R\&D expenditure external (RDEXT) (\% of total turnover) & 0.02 & 0.49 \\
\hline Communication sources - internal (COMMINT)** & 0.70 & 2.49 \\
\hline Communication sources - market (COMMMAR)** & 0.69 & 2.50 \\
\hline $\begin{array}{l}\text { Communication sources }- \text { universities and research institutes } \\
(\mathrm{COMMUNI})^{* *}\end{array}$ & 0.35 & 1.30 \\
\hline Communication sources - other $(\mathrm{COMMOTH})^{* *}$ & 0.54 & 1.69 \\
\hline$N$ & 58 & 253 \\
\hline \multicolumn{3}{|c|}{$\begin{array}{l}\text { Note. } * \text { EMPUD categories: } 0-0 \%, 1-1-4 \%, 2-5-9 \%, 3-10-24 \%, 4-25-49 \%, 5-50-74 \% \\
6-75-100 \% \text {, **Communication sources: importance was measured on the scale from } 0 \\
\text { not used to } 3-\text { highly important, maximum was used where multiple communication source } \\
\text { were available (market - suppliers, customers, competitors, and consultants; universities an } \\
\text { research institutes; and other - conferences, scientific journals, professional associations, an } \\
\text { internet). }\end{array}$} \\
\hline
\end{tabular}

Table 1 shows that there are significant differences between innovative and noninnovative enterprises. First, there was a relatively high proportion of innovative enterprises, i.e. $81.3 \%$ in the German information and communication creative sectors. Moreover, innovative enterprises in the dataset were specific in that the size of innovative enterprises (measured with total turnover) was relatively large when compared with the size of non-innovative enterprises in this sector. Innovative enterprises also have a higher proportion of employees with a university education. Expenditure on R\&D is dominated by in-house R\&D expenditure in both categories, being larger in innovative enterprises.

Another important determinant of innovation activity is represented by organisational competences, namely internal and external communication (Mention 2011). Souitaris (2002) shows that information from customers and suppliers is more important for innovation than information from public agents, private consultants, scientific journals, databases and trade fairs. Firms use the information from suppliers and customers as a stimulus for their innovation.

The determinants of innovation activity in Table 1 estimate: (1) size of enterprise (larger enterprises are generally expected to be more innovative owing to higher resources for innovation projects (Tang, 2006)); (2) human resource competences (the presence of strong communication linkages can contribute to an enterprise's innovative capabilities (Romijn \& Albaladejo, 2002); and (3) technological competences (intensity of R\&D usually approximates to $R \& D$ expenditure (Souitaris, 2002)). 
We further considered the markets in which enterprises sold goods and services, distinguishing local or regional $(51.1 \%$ of all enterprises in the dataset), national (85.6\%), EU (49.7\%) and other countries' markets (20.8\%), see Table 2 . In total, $37.8 \%$ of the enterprises were part of an enterprise group. International market competition is assumed to require higher innovation activity (Roper \& Love, 2002).

Table 2

Frequencies of Categorical Determiants for German Information and Communication Creative Industries

\begin{tabular}{ll}
\hline \multicolumn{1}{c}{ Determinant } & \multicolumn{1}{c}{ Frequencies } \\
\hline Geographic market (MARKET) Regional/National/EU/Other/Missing & $57 / 193 / 15 / 29 / 27$ \\
Part of an enterprise group (GROUP) Yes/No/Missing & $119 / 182 / 10$ \\
Collaboration on innovative activity (COLLAB) Yes/No/Missing & $118 / 169 / 24$ \\
National financial support (FUNNAT) Yes/No/Missing & $93 / 130 / 88$ \\
EU financial support (FUNEU) Yes/No/Missing & $33 / 190 / 88$ \\
\hline
\end{tabular}

Cooperation with other companies is a specific source of innovation incentives. It is more important than the collaboration with universities and research institutions (Souitaris, 2002). Based on the analysis of our sample we can state that innovative firms in the creative sectors collaborate closely on innovation activity with other enterprises or institutions. Public funding (national and EU) usually supports both collaborative and innovation activities (Stejskal and Hajek, 2015).

The variety of the above-mentioned determinants makes it possible to examine numerous effects on both collaboration and innovation activity in German information and communication creative industries.

\section{EXPERIMENTAL RESULTS}

Strong relationships between the determinants would result in multicollinearity in the dataset. To address this issue, we performed collinearity diagnostics using variance inflation factors (VIF). The maximum value of VIF was 2.67 (i.e. below 5), indicating no evidence of multicollinearity. Therefore, we used the determinants introduced in the previous section as input variables in regression models as presented in Table 3. 
Table 3

Expected Effects of Input Variables in Regression Models

\begin{tabular}{|c|c|c|c|}
\hline Determinant & $\begin{array}{c}\text { Model } 1 \\
\text { Output - COLLAB } \\
(\text { yes/no })\end{array}$ & $\begin{array}{c}\text { Model } 2 \\
\text { Output - } \\
\text { INNOV } \\
\text { (yes/no) }\end{array}$ & $\begin{array}{c}\text { Model 3 } \\
\text { Output }- \text { TURNINNOV } \\
\text { (numerical) }\end{array}$ \\
\hline $\ln (T U R N)$ & + & + & + \\
\hline EMPUD & + & + & + \\
\hline RDINT & + & + & + \\
\hline RDEXT & + & + & + \\
\hline COMMINT & + & + & + \\
\hline COMMMAR & + & + & + \\
\hline COMMUNI & + & + & + \\
\hline СОММОТН & + & + & + \\
\hline MARKET & + & + & + \\
\hline GROUP & + & + & + \\
\hline COLLAB & & + & + \\
\hline FUNNAT & + & + & + \\
\hline FUNEU & + & + & + \\
\hline
\end{tabular}

In the collaboration model (Model 1), the output variable was represented by 0 for no collaboration and 1 for collaboration activity. Similarly, non-innovative and innovative firms were distinguished in Model 2. Logistic regression models were used in case of these models. Finally, linear regression model was used to estimate the effects on numerical variable TURNINNOV in Model 3.

To estimate the quality of the logistic regression models we used approximations of the coefficient of determination, namely Cox and Snell's $R^{2}$ which is based on the $\log$ likelihoods for the model and baseline model, and Nagelkerke's $R^{2}$ which is an adjusted version of the Cox \& Snell $R^{2}$. For Model 1, information obtained from universities, market competition and national/EU financial support were significantly positive determinants of collaboration activity (Table 4). It seems that workers with university degree is not a prerequisite to creation of cooperation and the creation of innovative output. It is primarily due to the expansion of university degrees in the general population (a large proportion of the workforce has a university degree, but incompatible to their labor position). Likewise, it was demonstrated that the external R\&D expenditures are an essential condition for the realization of the innovative results, not to establish cooperation (to do the cooperation the internal $\mathrm{R} \& \mathrm{D}$ expenditures are enough). 
On the other hand, internal and market communication, market competition and collaboration were significantly promoted innovation activity in Model 2.

Table 4

Collaboration and Innovation Logistic Regression Models

\begin{tabular}{|c|c|c|c|c|}
\hline \multirow[t]{2}{*}{ Determinant } & \multicolumn{2}{|c|}{$\begin{array}{c}\text { Model } 1 \\
\text { COLLAB }\end{array}$} & \multicolumn{2}{|c|}{$\begin{array}{l}\text { Model } 2 \\
\text { INNOV }\end{array}$} \\
\hline & $B$ coef. & $p$-value & $B$ coef. & $p$-value \\
\hline $\ln (T U R N)$ & .074 & .526 & .209 & .284 \\
\hline EMPUD & -.071 & .620 & -.048 & .795 \\
\hline RDINT & 2.683 & .247 & -5.967 & $.039 * *$ \\
\hline RDEXT & -17.086 & .101 & 84.171 & .340 \\
\hline COMMINT & .085 & .688 & .743 & $.004 * * *$ \\
\hline COMMMAR & .386 & .132 & 1.044 & $.000 * * *$ \\
\hline COMMUNI & .779 & $.000 * * *$ & -.198 & .529 \\
\hline СОММOTH & -.425 & $.052 *$ & .262 & .378 \\
\hline MARKET & .374 & $.097 *$ & .760 & $.037 * *$ \\
\hline GROUP & .598 & .172 & -.931 & .144 \\
\hline COLLAB & - & - & 2.981 & $.012 * *$ \\
\hline FUNNAT & 2.485 & $.000 * * *$ & .165 & .855 \\
\hline FUNEU & 1.264 & $.064 *$ & .024 & .984 \\
\hline Constant & -4.724 & $.014 * *$ & -6.395 & $.046^{* *}$ \\
\hline Cox \& Snell $R^{2}$ & .399 & & .421 & \\
\hline Nagelkerke $R^{2}$ & .546 & & .666 & \\
\hline
\end{tabular}

Legend: * significant at $P<0.10,{ }^{* *}$ significant at $P<0.05, * * *$ significant at $P<0.01$.

Specifically, information sources were important for the innovation model, particularly information from market sources such as clients and competition. In addition, a focus on markets other than those in the EU was a positive determinant of innovation activity in these creative industries. The values of the $R^{2}$ coefficients showed that both collaboration and innovation activity were partly explained using the chosen determinants. In addition, the classification accuracies of the models were $81.7 \%$ for collaboration and $92.8 \%$ for innovation activity, respectively.

To further examine the role of the determinants in innovation performance, we tested their influence on the economic effect of innovation activity in terms of 
the percentage of innovative products in total turnover (TURNINNOV). First, we selected the standard Enter method in IBM SPSS Statistics 19 to estimate the simultaneous effects of all independent variables (they were entered into the equation at the same time) in Model 3a (Table 5). To improve the quality of the regression model, we further employed backward elimination that deletes one determinant at a time if it does not contribute to the regression model. Thus, the determinants were retained based on their statistical contribution. In Table 5, we present the models (Model 3b and Model 3c) with the highest values of Adjusted $R^{2}$. In both models, external R\&D expenditure and internal communication were the significant drivers of innovative turnover.

Table 5

Linear Regression Models for Innovative Turnover

\begin{tabular}{|c|c|c|c|c|c|c|}
\hline \multirow[t]{2}{*}{ Determinant } & \multicolumn{2}{|c|}{$\begin{array}{c}\text { Model 3a } \\
\text { TURNINNOV }\end{array}$} & \multicolumn{2}{|c|}{$\begin{array}{c}\text { Model 3b } \\
\text { TURNINNOV }\end{array}$} & \multicolumn{2}{|c|}{$\begin{array}{c}\text { Model 3c } \\
\text { TURNINNOV }\end{array}$} \\
\hline & $B$ coef. & $p$-value & $B$ coef. & $p$-value & $B$ coef. & $p$-value \\
\hline $\ln (\mathrm{TURN})$ & -.033 & $.009 * * *$ & -.034 & .006 & -.034 & .005 \\
\hline EMPUD & .012 & .353 & .014 & .273 & .015 & .220 \\
\hline RDINT & .118 & .554 & - & & - & \\
\hline RDEXT & .912 & .337 & 1.367 & $.030 * *$ & 1.333 & $.034 * *$ \\
\hline COMMINT & .033 & .116 & .035 & $.092 *$ & .037 & $.069 *$ \\
\hline COMMMAR & .043 & $.069 *$ & .041 & $.075^{*}$ & .040 & $.084 *$ \\
\hline COMMUNI & .003 & .880 & - & & - & \\
\hline СOMMOTH & .024 & .274 & .026 & .193 & .026 & .195 \\
\hline MARKET & .030 & .157 & .030 & .152 & .029 & .173 \\
\hline GROUP & -.058 & .165 & -.060 & .150 & -.064 & .119 \\
\hline COLLAB & .027 & .548 & .039 & .319 & .048 & .204 \\
\hline FUNNAT & .009 & .852 & - & & - & \\
\hline FUNEU & .050 & .415 & .054 & .373 & - & \\
\hline Constant & .422 & $.033 * *$ & .432 & $.027 * *$ & .435 & $.025^{* *}$ \\
\hline$R^{2}$ & .237 & & .236 & & .233 & \\
\hline Adjusted $R^{2}$ & .193 & & .202 & & .202 & \\
\hline
\end{tabular}

Legend: * significant at $P<0.10, * *$ significant at $P<0.05, * * *$ significant at $P<0.01$. 


\section{CONCLUSION}

Our research contributes to the literature in several ways. Firstly, we have empirically shown that enterprises from information and communication industries can create innovations through the collaboration. Secondly, we confirmed that both internal and external communication significantly contribute to the creation of innovation. Internal communication contributes to a lesser extent than the external one. Enterprises can create innovation more effectively by collaborating with other organizations, but its economic effects were not significant.

In contrast to previous studies on knowledge-based determinants of collaboration and innovation activity (Liao \& Wu, 2010), we focused on creative industries. In these creative industries, where a new idea or thought constitutes a new result (typically software, graphic, multimedia), we have shown the greater effect of internal and market communication and spill-over effects from external collaboration based on communication with universities. The results of our research have other policy implications. These relate mainly to two areas of support. The first is strategic support, which includes support for activities utilizing the collaboration between enterprises or the knowledgebased sector. Here we can see the role of public sector organizations, which can become mediators or institutions for collaboration (as is often the case in industrial clusters for example). The practical implication is support for the establishment of regional innovation systems, which can create a favourable environment for the transfer of tacit knowledge, spill-over effects and their use to create commercial sable results (Matatkova \& Stejskal, 2013; Hajek et al., 2014, Stejskal et al. 2015).

The second implication relates to financial support. The research has shown that innovative enterprises in creative industries received more public financial support for innovation activities from all levels of government. Public administration should continue to support innovative enterprises in areas that create commercial sable innovation. However, we should point out a frequently occurring phenomenon called the innovation paradox, which describes the danger of investing public funds into industries and enterprises that fail to transform this support into innovation.

Examination of the individual determinants affecting innovation in creative industries of the Czech economy reveals the following conclusions. The monitored creative industries are specific in terms of the determinants. A key role is played by the acquisition of knowledge, particularly from clients and competitors. 
As in the manufacturing sector (Belderbos et al. 2004; Murovec \& Prodan, 2009) the significant effects was determined based on the market information (communication sources from market) and no significant effect on amount of public expenditure on research and development or on the innovation or collaboration of enterprises. We confirmed the influence of internal expenditures on $R \& D$ (it supports the innovative products). In all three regression models, we observed significant influence of external expenditures on $R \& D$. The lack of internal firm capital may be the reason. If the firms want to innovate (and need some extra investments), they can turn on interconnected firm ("mother") with requests for capital, as well as FDI come into the country as foreign capital, which is invested in science, research, technology and innovation. Surprisingly, the number of university-educated workers has been identified as a no significant determinant that leads to higher turnover of innovative production (confirmed all three regression models). Specifically, the information and communication and other connected industries don't necessary require a university degree (the creativity is not associated with the university degree).

It was shown that communication creative industries are specific industry and the crucial determinants must be subjects to further research before their influence can be defined definitively.

\section{ACKNOWLEDGMENT}

This work was supported by a grant provided by the scientific research project of the Czech Sciences Foundation Grant No: 17-11795S.

\section{REFERENCES}

Ali, A., Nor, H., Nor, R., Abdullah, R., \& Azmi Murad, M. A. (2016). Developing conceptual governance model for collaborative knowledge management system in public sector organisations. Journal of Information and Communication Technology, 15(2), 171-191.

Asheim, B. T., \& Hansen, H. K. (2009). Knowledge bases, talents, and contexts: On the usefulness of the creative class approach in Sweden. Economic Geography, 85(4), 425-442.

Asheim, B. T., Coenen, L., Moodysson, J., \& Vang, J. (2007). Constructing knowledge-based regional advantage: Implications for regional 
innovation policy. International Journal of Entrepreneurship and Innovation Management, 7(2), 140-155.

Asheim, B., \& Gertler, M. 2005. The geography of innovation: Regional innovation systems. In J. Fagerberg, D.C. Mowery, \& R. R. Nelson, The Oxford Handbook of Innovation (pp. 291-317). Oxford, U.K.: Oxford University Press.

Bakhshi, H., Freeman, A., \& Higgs, P. L. (2013). A dynamic mapping of the UK's creative industries. London: CCI.

Balkyte, A., \& Tvaronavičiene, M. (2010). Perception of competitiveness in the context of sustainable development: Facets of "sustainable competitiveness". Journal of Business Economics and Management, 11(2), 341-365.

Belderbos, R., Carree, M., Diederen, B., Lokshin, B., \& Veugelers, R. (2004). Heterogeneity in R\&D cooperation strategies. International Journal of Industrial Organization, 22(8), 1237-1263.

Blažek, J., Zizalová, P., Rumpel, P., \& Skokan, K. (2011). Where does the knowledge for knowledge-intensive industries come from? The case of biotech in Prague and ICT in Ostrava. European Planning Studies, 19(7), 1277-1303.

Boix, R., De-Miguel-Molina, B., \& Hervas-Oliver, J. L. (2013). Creative service business and regional performance: Evidence for the European regions. Service Business, 7(3), 381-398.

Camelo-Ordaz, C., Fernández-Alles, M., Ruiz-Navarro, J., \& Sousa-Ginel, E. (2012). The intrapreneur and innovation in creative firms. International Small Business Journal, 30(5), 513-535.

Carneiro, A. (2000). How does knowledge management influence innovation and competitiveness?. Journal of Knowledge Management, 4(2), 8798.

Chapain, C., \& De Propris, L. (2009). Drivers and processes of creative industries in cities and regions. Creative Industries Journal, 2(1), 9-18.

Charrass, A. (2016). New criticism on the competitiveness concept: A critical review of the concept at the macroeconomic level. International Journal of Economics and Finance, 9(1), 190-193. 
Cooke, P., \& Leydesdorff, L. (2006). Regional development in the knowledgebased economy: The construction of advantage. The Journal of Technology Transfer, 31(1), 5-15.

Godin, B. (2006). The knowledge-based economy: Conceptual framework or buzzword? The Journal of Technology Transfer, 31(1), 17-30.

Hajek, P., Henriques, R., \& Hajkova, V. (2014). Visualising components of regional innovation systems using self-organizing maps - Evidence from European regions. Technological Forecasting and Social Change, 84, 197-214.

Hajkova, V., \& Hajek, P. (2014). Efficiency of knowledge bases in urban population and economic growth - Evidence from European cities. Cities, 40, 11-22.

Hollenstein, H. (2004). Determinants of the adoption of Information and Communication Technologies (ICT): An empirical analysis based on firm-level data for the Swiss business sector. Structural change and Economic Dynamics, 15(3), 315-342.

Holsapple, C. W., \& Singh, M. (2001). The knowledge chain model: Activities for competitiveness. Expert Systems with Applications, 20(1), 77-98.

Karaev, A., Lenny Koh, S. C., \& Szamosi, L. T. (2007). The cluster approach and SME competitiveness: A review. Journal of Manufacturing Technology Management, 18(7), 818-835.

Kimpeler, S., \& Georgieff, P. (2009). The roles of creative industries in regional innovation and knowledge transfer - The case of Austria. In E. Villalba (Ed.), Measuring creativity (pp. 207-221). Luxembourg: OPOCE.

Kitson, M., Martin, R., \& Tyler, P. (2004). Regional competitiveness: An elusive yet key concept?. Regional Studies, 38(9), 991-999.

Krugman, P. (1994). Competitiveness: A dangerous obsession. Foreign Affairs - New York, 73, 28-28.

Laperche, B., Lefebvre, G., \& Langlet, D. (2011). Innovation strategies of industrial groups in the global crisis: Rationalization and new paths. Technological Forecasting and Social Change, 78(8), 1319-1331. 
Liao, S. H., \& Wu, C. C. (2010). System perspective of knowledge management, organizational learning, and organizational innovation. Expert Systems with Applications, 37(2), 1096-1103.

Lucas, R. E. (1988). On the mechanics of economic development. Journal of Monetary Economics, 22(1), 3-42.

Marrano, M. G., Haskel, J., \& Wallis, G. (2009). What happened to the knowledge economy? ICT, intangible investment, and Britain's productivity record revisited. Review of Income and Wealth, 55(3), 686-716.

Matatkova, K., \& Stejskal, J. (2013). Descriptive analysis of the regional innovation system-Novel method for public administration. Transylvanian Review of Administrative Sciences, 39, 91-107.

Mention, A. L. (2011). Co-operation and co-opetition as open innovation practices in the service sector: Which influence on innovation novelty? Technovation, 31(1), 44-53.

Merickova Mikusova, B., \& Stejskal, J. (2014). Value of Collective Consumption Goods. Politicka Ekonomie, 62(2), 216-231.

Miles, I., \& Green, L. (2008): Hidden innovation in the creative industries. London: NESTA Research Report.

Monfardini, E., Probst, L., Szenci, K., Cambier, B., \& Frideres, L. (2012). "Emerging industries": Report on the methodology for their classification and on the most active, significant and relevant new emerging industrial sectors. European Union, Research Report.

Müller, K., Rammer, C., \& Trüby, J. (2009). The role of creative industries in industrial innovation. Innovation, 11(2), 148-168.

Murovec, N., \& Prodan, I. (2009). Absorptive capacity, its determinants, and influence on innovation output: Cross-cultural validation of the structural model. Technovation, 29(12), 859-872.

Porter, M. (2003). The economic performance of regions. Regional Studies, $37(6-7), 545-546$. 
Porter, M. E. (2004). Building the microeconomic foundations of prosperity: Findings from the business competitiveness index. World Competitiveness Report, 2005.

Porter, M. E., \& Porter, M. P. (1998). Location, dlusters, and the "New" microeconomics of competition. Business Economics, 33(1), 7-13.

Prokop, V., \& Stejskal, J. (2017). Different approaches to managing innovation activities: An analysis of strong, moderate, and modest innovators. Engineering Economics, 28(1), 47-55.

Prokop, V., Stejskal, J. (2015). Impacts of local planning to competitiveness index change - Using approximate initial analysis to the Czech regions. WSEAS Transactions on Business and Economics, 12(1), 279-288.

Ramayah, T., Mohamad, O., Omar, A., Marimuthu, M., \& Leen, Y. A. (2013). Determinants of technology adoption among Malaysian SMEs: An IDT perspective. Journal of Information and Communication Technology, 12, 103-119.

Romijn, H., \& Albaladejo, M. (2002). Determinants of innovation capability in small electronics and software firms in southeast England. Research Policy, 31(7), 1053-1067.

Roper, S. \& Love, J. H. (2002). Innovation and export performance: Evidence form UK and German manufacturing plants. Research Policy, 31(7), 1087-1102.

Siegel, D. S., Waldman, D. A., Atwater, L. E., \& Link, A. N. (2003). Commercial knowledge transfers from universities to firms: Improving the effectiveness of university-industry collaboration. The Journal of High Technology Management Research, 14(1), 111-133.

Skokan, K. (2004). Competitiveness, innovation and clusters in regional development. (1st ed.). Ostrava: Repronis.

Souitaris, V. (2002). Firm-specific competencies determining technological innovation: A survey in Greece. $R \& D$ Management, 32(1), 61-77.

Stejskal, J., \& Hajek, P. (2015). Modelling knowledge spillover effects using moderated and mediation analysis - The case of Czech high-tech industries. International Conference on Knowledge Management in Organizations, Springer International Publishing, 329-341. 
Stejskal, J., \& Hajek, P. (2016). Determinants of collaboration and innovation in creative industries: A case of the Czech Republic. In: Proceedings of Knowledge Management International Conference (KMICe) 2016, 116-121.

Stejskal, J., Merickova, B. M., \& Prokop, V. (2016). Consequences of enterprises' cooperation within the innovation process - case study of the Czech Machinery Industry. E \& M Ekonomie a Management, 19(3), 110-122.

Stejskal, J., Nekolova, K., \& Rouag, A. (2015) The use of the weighted sum method to determine the level of development in regional innovation systems - Using Czech Regions as example. Ekonomicky Casopis, 63(3), 239-258.

Tang, J. (2006). Competition and innovation behaviour. Research Policy, 35(1), $68-82$.

Turuk, M., \& Labas, D. (2015). Firm survival in European economies. In Proceedings of 7th Annual American Business Research Conference. 23 - 24 July 2015, New York, USA.

Ulengin, F., Ulengin, B., \& Onsel, S. (2002). A power-based measurement approach to specify macroeconomic competitiveness of countries. SocioEconomic Planning Sciences, 36(3), 203-226. 